\title{
The Regeneration of Ulamas Moderate and Tolerant Through Education Dinyiah Formal in Salafiyah Pesantren
}

\author{
A.M. Wibowo ${ }^{1}$, Akhmad Muntakhib ${ }^{2}$, Titi Isnaini Fauzah ${ }^{3}$, Nurul Huda ${ }^{4}$ and Marmiati \\ Mawardi ${ }^{5}$ \\ \{attara.wibowo@gmail.com¹, amuntakhib88@gmail.com², tifaghalidza@yahoo.com³ \\ denmasaam@yahoo.com ${ }^{4}$,nurulhuda000008888@gmail.com ${ }^{5}$ \} \\ Religious Research, Development and Training Agency, Ministry of Religious Affair ${ }^{1}$ \\ Religious Research, Development and Training Agency, Ministry of Religious Affair ${ }^{2}$ \\ Religious Research, Development and Training Agency, Ministry of Religious Affair ${ }^{3}$ \\ The Ministry of Religion Affair Banjarnegara District ${ }^{4}$ \\ Religious Research, Development and Training Agency, Ministry of Religious Affair ${ }^{5}$
}

\begin{abstract}
This article is about study implementation education at Education Diniyah Formal (EDF) in 5 Salafiyah Islamic boarding schools in Central and East Java in forming moderate Ulamas who have tolerant values. This research departs from a concern about moderate Indonesian Ulama scarcity and tolerance values amid the onslaught ideology fundamentalist which rubs against the mainstream Islam embraced by Indonesian society. Government with the Minister of Religion Regulation No. 13 Year 2014 has tried to regenerate, reproduce moderate and tolerant Ulama candidates to counter radicalism in Indonesia. By using qualitative approach this study has found two findings, there are; firstly, the cadres' formation in Education Diniyah Formal at Islamic Boarding School (pesantren) was carried out by processing students input with curriculum and asatidz resources to produce students (santri outputs) that were mutafaqqih fiddin and inspirit tolerant values. Secondly, the form of ulama's cadre moderate and tolerant regeneration through EDFs at the Ulya level is done through factual curriculum and hidden curriculum. However, among the most instrumental in forming the character of students who having tolerant values is hidden curricula implementation as the core of Islamic boarding school.
\end{abstract}

Keywords: The Reproduction, moderate, tolerant, Ulama, Education Diniyah Formal, salfiyah pesantren.

\section{Introduction}

There is no great person in Indonesia who is not escorted by the Ulama because Ulama in the sociology point of view is a center of the relationship between Islam and Muslims and daily life. Ulama have a major contribution to the life of community both ideology, politics, social, politics and security [1] [2]. Ulama often presents themselves as decisive figures in the life of Muslims on a historical stage that deals with issues of government, politics, socio-cultural, and education. The formation of Muslim society and its 
sustainability cannot be separated from the role of Ulama. Conversely, Muslim communities have a stake in the regeneration of scholars in a sustainable manner [3].

After reformation and entering a disruptive era, Indonesia faced challenges that began and turmoil in the Middle East spread to Indonesia. Currently, Indonesia is a "battle" place between fundamentalism ideological from Middle Eastern (Islamic) countries with an Islamic mainstream which moderate understanding. The invasion of ideology originating from the Middle East gave birth to movements that rubbed against ideology that had become mainstream adherents of Islam in Indonesia. Ideology that developed in Indonesia is a moderate and tolerant with local culture usually taught in salafiyah Islamic boarding schools through Classical Islamic Manuscript (Kitab Kuning).

Indonesia has not yet brought forth the tolerant ulama (parsons) to stand in and continue struggles such as Gus Dur (KH Abdurrahman Wahid), Cak Nur (Nurkholis Madjid), KH Sahal Mahfudz, KH. Maemoen Zubair, and Buya Syafii (Syafii Ma'arif), they are role of the community (ummah) models. Da'wah preaching is cool and the fatwa is obeyed because it is easily digested by public. Religious education is a way for people to understand religion or tafaqquh fi al-din. Understanding religion true and moderate becomes a basic requirement for every human being in living his life.

The Indonesian state needs to implement policies to solve problems currently faced as mentioned above. One of them is through education in collaborating with Islamic boarding schools to cadre, produce and to make an edition moderate Ulamas who have tolerant values to overcome how the problem to do moderation as a counter radicalism. This is because Islamic education has a strong relationship with the citizens lives in a strengthening way moderation sense, nationalism which is realized by unity, between groups. Islamic education can be an role model in guiding and educating people who uphold and practice tolerance and statehood values in life of the nation and state. Islamic education can actualize national unity, by various religions, tribes, and races[4]. By producing tolerant Ulama, the jargon religion Islam as a of rahmatan lil alamin which became majority religion in Indonesia returned to normal, namely moderate and tolerant Islam.

Government the Republic of Indonesia Government Regulation Number 55Year 2007 concerning religious education and religious education which is about diniyah education and regarding pesantren or Islamic boarding school. The regulation about existence education institutions religious, both pesantren and diniyah education, which are a necessity for Muslims. It is hoped that through Islamic boarding school education tolerant scholars born who can moderate and counter radicalism in Indonesia. Efforts made by the pesantren and the government are formation of Education Diniyah Formal (EDF)

Education Diniyah Formal (EDF) is subject to Regulation of the Minister Religious Affair (PMA) Number 13-year 2014 concerning Islamic Religious Education, which is a derivative of Government Regulation Number 55-Year 2007 concerning Religious Education and Religious Education, which is implementation The Law Number 20 year 2003 concerning the National Education System. EDF is one of the institutional Islamic religious education which is formal to produce graduates of mutafaqqih fiddin (Islamic religious experts) to answer mutafaqqih fiddin scarcity cadres. EDF is part of a large scenario to make education in Indonesia, especially pesantren, an educational destination. In organizing their education, EDF as one of Islamic religious education institutions is obliged to instill faith and piety in Allah SWT. The organizing purpose of EDF is to develop personal virtues, mercy, individual and social piety, uphold the values of sincerity, simplicity, independence, brotherhood among Muslims, humble, tawadlu, tolerant 
(tasamuh), equality (tawazun), moderate (tawasuth), be role model (uswah), healthy lifestyle, and patriotism[5].

Until 2018 out of thousands of Islamic boarding schools in Indonesia, there were only 60 Education Diniyah Formal Wustho and Ulya, which were recognized by Government in cooperation with Islamic boarding schools. This number has grown since 2015, which was only 15 EDFs. The EDF is spread in 13 provinces in Indonesia, namely D.I. Aceh, DI Yogyakarta, DKI Jakarta, Jambi, West Java, Central Java, East Java, South Kalimantan, North Kalimantan, West Nusa Tenggara, Riau, West Sulawesi, and South Sulawesi.

This paper aims to describe, explore and analyze the EDF role at Islamic boarding schools in Central and East Java that cadre moderate Ulama who have 12 characters of tolerant Ulama with character of morality, pious individually and socially at Ulya level. The 12 tolerant Ulama characters cover sincerity, simplicity, independence, brotherhood among Muslims, humble, tawadlu, tolerant, equality, moderate, role models (uswah), healthy lifestyle, healthy life, and love the country values.

The subjects of this study taken at Ulya EDF level on Salafiyah Islamic Boarding Schools which held EDFs in Pekalongan, Wonosobo, and Kendal Regencies at Central Java and Magetan, Lirboyo at East Java. EDFs selected as the research subject at Central Java are EDF Walindo Manbaul Falah Siti Zaenab KPBR IV Pekalongan, Al Mubaarok Wonosobo, APIK Kaliwungu Kendal, at East Java selected Al Mahrusyiyah Lirboyo, and Cokrokertopati Magetan Regency. These whole research objects are EDFs under the firstgeneration boarding school of Education Diniyah Formal.

\section{Theoretical framework}

\subsection{Salafiyah Islamic boarding school and education diniyah formal}

Salafiyah boarding school is an Islamic educational institution with a boarding system. There are 5 salafiyah boarding school elements; they are pondok (cottage), Kyai, Kitab Kuning (Classical Islamic manuscript), mosque, and Santri [6]. The mosque is a central point that animates to understand, Islam live teachings (tafaqquh fi al-din) through study of Koran, Hadith and the Classical Islamic Manuscripts. The teaching methods commonly used in the Salafiyah Boarding School are sorogan, bandongan, istighasah, wetonan and mudzakaroh to achieve sublimation between Islamic scientific intelligence and transcendent intelligence both in the view of Allah SWT and human views.

Education Diniyah Formal is part of the Pesantren or Islamic boarding school. The difference between EDF with another Islamic boarding school that EDF is diplomatically recognized and equated with the formal school by government. EDF is an education in which all subjects are Islam religion sciences, covering jurisprudence, interpretation, tauhid (monotheism), wisdom and other religious Islam sciences [7]. With such dense and complete religious knowledge material, it is possible for students who study in it to have a better religious sciences mastery.

The Minister of Religion regulation No. 13 Year 2014 told about concerning Islamic Religious Education regulates requirements for Education Diniyah Formal establishment which covers a formal diniyah education curriculum, adequate qualifications and educators number, facilities and infrastructure of learning activities within the pesantren environment, 
has an educational evaluation system, has prospective students more than 300 people and attach ability to implement the curriculum set by government.

\subsection{Islamic boarding school curriculum}

The Islamic boarding school (pesantren's curriculum) is Classical Islamic Manuscript book. The book becomes something substantial as EDF reference. Therefore, in development of pesantren which are increasingly dynamic and following the development of national education, Islamic boarding schools still support the Classical Islamic Manuscript as teaching material. The Classical Islamic Manuscript book is a book that balagh (guidance book) in Islamic boarding schools with the Islamic sciences study. According to Saifuddin Zuhri the Classical Islamic Manuscript is better known as the "book of kurosan" with the pages in the book in the unraveling unwinds form [8]. The Classical Islamic Manuscript in Islamic boarding schools has a different diversity between one boarding school and another boarding school. However, the Classical Islamic Manuscript curriculum material among Islamic Boarding Schools is related to fiqh, ushul fiqh, hadith, tafsir, tauhid, tasawuf, and akhlaq (ethics).

\subsection{Ulama}

Ulama are those who are experts or have advantages at field of science in Islam, such as experts in interpretation, hadith science, Kalam science, Arabic and its parameters such as Sharaf, Nahwu, Balaghah and so on [9]. They indeed cannot be separated from religion and community. Ulama often present themselves as decisive figures in the life of Muslims on historical stage, relations with government, political, socio-cultural, and educational issues. Kyai occupies a special position in inseparable from tradition prevailing on santri community, especially in the countryside, which assumes that in religion and daily life one must obey what they have inherited. The Ulama acted as heir to the Prophet [10]. Another Ulama name is Muslim Scholar, but Muslim scholar are not necessarily Muslim, for example just Snouck Hurgonye. A Muslim scholar who meets the criteria of ulama when he has a pious people figure criteria that is not only a scientific aspect but also the quality of daily charity [11].

\subsection{Effective education}

Effective teaching in education can be developing by process input in educational institutions as expected outputs. In forming a cadre tolerant Ulama context of through EDF, an effective EDF education can be by processing the inputs available in madrasah to produce product Ulama cadres who have tolerant character. Windham (1990) supplies several overview indicators the education effectiveness covering input, process, and output [12]. Input indicators involve students, teacher characteristics, facilities, infrastructure, educational materials, educational ability Process indicators include administrative attitudes, teacher time allocation, and student time allocation. The output indicators involve achievement effect, behavioral effect, and leveling effect.

In the context of EDF, intended input covering students, facilities and curriculum. The Educational process in EDF includes learning preparation, learning models, time allocation, Classical Islamic Manuscript learning, extra-curricular, and evaluation. In the output 
context EDF, intended output involve cadres Ulama who have personal good behavior (Ahlakul karimah), individual and social piety, upholding values of sincerity, simplicity, independence, brotherhood among Muslims, humble, tawadlu, tolerant (tasamuh), equality (tawazun), moderate (tawasuth), be role model (uswah), healthy lifestyle, and love for the motherland.

\section{The regeneration ulama moderates and tolerant through EDF}

The regeneration Ulamas tolerant in this study covering input, process output EDFs and pesantren as core of entire education system Pesantren environment. Input components involve santri participation in their motivation to study in Education Diniyah Formal. The Process component includes asatidz competencies, factual and hidden curriculum also learning methods. The output component involving aspirations santri recruiting to become Ulama candidates who are mutafaqqih fiddin who have values sincerity, simplicity, independence, brotherhood among Muslims, humble, tolerant (tasamuh), equality (tawazun), moderate (tawasuth), exemplary (uswah), a healthy lifestyle, and Love the motherland.

Here participation, the students who took Ulya's education at 5 EDF Ulya on Islamic boarding school research subjects can be distinguished based on educational background and learning motivation at Ulya EDF specifically and general in pesantren. Based on educational background of santri, participation of santri who registered with EDF students came not only from they who continued their education at each pesantren but also from other salafiyah boarding school who wished to continue their education at EDF on research subjects.

However, there were not too many students from outside salafiyah boarding school EDF where there were studied. The students at EDF Ulya were more dominated by alumni in the huts of each islamic boarding school organizer. For students from another boarding school, this condition certainly needs making adjustments (i'dadiyah) for 1 year for curriculum equality. This is because Classical Islamic Manuscript curriculum used in each EDF Ulya is sometimes not the same. Book Nahwu shorof in EDF on research subjects using Alfiyah ibn Malik, Al-Husuun al-Hamidiyah, Khasiyyah ad Dasuki. However, many books that are taught on EDF Ulya on Islamic boarding schools more similarities between EDF Ulya with each other both at Wustho level and Ulya level. Similarity with the book at Wustho level makes it easy for Ulya EDF managers to accept students from other Islamic boarding schools. Some similarities of islamic classical manuscript such as Book of Khulasoh al-Nur al-Yaqin, Al Arobiyyah baina Yadaik, Arbain al-Nawawi, Adab alMuat'alim and others.

The learning process in EDF includes asatidz with each competencies, factual curriculum, hidden curriculum, and evaluation assessment. Through educational process in EDF on the pesantren objectives and EDF ulya in general are to form santri as cadres of Ulama who are mutafaqqih fiddiin and have sincerity values, simplicity, independence, brotherhood among muslims, humility, tolerance (tasamuh), equality (tawazun), moderate (tawasuth), be role model (uswah), healthy lifestyle, and love the motherland as output will be achieved. 


\subsection{Asatidz}

Judging from the teacher (asatidz), the Parsons (Ulama, Kiai, and Teacher) who teach at EDF boarding schools on research subjects are mostly from alumni of Islamic boarding schools where EDF boarding schools are held (EDF APIK and al Mubaarok) except at EDF boarding schools Walindo and Al-Mahrusiyyah Lirboyo. Judging from pedagogical the educator's competence on EDF pesantren are different from another pesantren. But in general, they are graduates from islamic boarding schools.

Asatidz EDF Ulya islamic boarding school mostly has a formal high school diploma and boarding school. Most student on EDF at Walindo are not graduates from Walindo islamic boarding school, but graduates from al-Raudloh boarding school in Pasuruan, alFalahiyah Mlangi Sleman, al-Anwar Sarang Rembang, API Tegalrejo Magelang, Manbaul Ulum Pati, Al-Masariqul Anwar Cirebon, An-Falahiyah Mlangi Sleman Nur Lasem, Bahrul Ulum Tambak Beras, Kyai Parak Bambu Runcing Temanggung, Darul Falah Jepara. Whereas in EDF Al Mubaarok Manggisan Wonosobo are Al Mubaarok alumni. This also happened at APIK Kaliwungu Kendal boarding school, almost all of the asatidz were Pondok APIK graduates with a disposition from khodimul ma'had.

In Al Mahrusyiyyah Lirboyo Boarding School data obtained that average asatidz in that Boarding School even educated Islamic boarding school and formal bachelor's degree, both from within the country and overseas (Yemen, Egypt and others. Salafiyah boarding school on EDF Ulya Al Mahrusyiyyah and even educated from formal bachelor's degrees, both from within country and overseas (Yemen, Egypt etc.) having asatidz who are educated even in Master or even Doktorate if viewed from the background of his pesantren EDF Ulya Al Mahrusyiyyah has an educational background from Hidayatul Mubtadiin Lirboyo, Al Mailki A Rushoifah Mecca, Al Afgah University of Yemen, Gajahmada University.

Pesantren EDF Cokrokertopati Takeran Magetan has asatidz graduates from outside the Cokrokertopati pesantren. In total there were 23 parsons. Judging from formal education, some ustadz are graduates from overseas such as Libya (1 person), Egypt (2 people), Tunisia (1 person). From the 23 religious teachers, 17 were undergraduate graduates and 6 were masters.

\subsection{Factual curriculum}

The Ulya EDF level curriculum which applied to all research subjects refers to the decision No. 6063-Year-2014 the Director General of Islamic Education concerning Ulya Formal Education Early Curriculum. Ulya's EDF curriculum seeks to develop education on a philosophical basis as an effort to develop the ability of santri to become qualified Indonesian Muslim people who master in Islamic religious sciences and can contribute to social life. The Diniyah Formal Education curriculum is rooted in the pesantren tradition to form a complete human being who can carry out the caliphate role on earth and at same time as a servant of God who must devote himself solely to God in carrying out that role.

The curriculum development in EDF is also based on tradition which is oriented to mastery the Classical Islamic Manuscript which is one of the characteristics in Islamic boarding schools. That manuscript book can effort to Ulama generate 'which is mutafaqqih fiddin to create moderate values student. That manuscript learning activity not only carried out in the classroom, but also in the foyer boarding school with the mosque as center in pesantren activities. EDF learning needs to be accompanied by a purification process of the heart which is carried out through various ubudiyyah (ritual activity), mujahadah (a war 
against deviation from true religion principles) and riyadhah (Doing to get used to carrying out ritual and social worship) activities to get closer to God and not to seek grandeur and position.

Subjects included in curriculum structure EDF 'Ulya consists of groups subjects Islamic religious, general education, and local content. The curriculum structure includes subjects covering Koran, Tafsir-Tafsir science, Hadith science of Hadith, Tawhid, Fiqh and Usul Fiqh, Ahlaq-Tasawuf, History of Islam (Tarikh), Arabic, Nahwu Shorof, Balaghah, Kalam, Arudh, and Falak. Local subjects include civic education, Indonesian Language, Mathematics, Natural Sciences, and Cultural Arts.

The Koran in the Education Diniyah Formal level Ulya involves Tahsinut Tilawah, Tafsir and Tafsir science, Hadith Sciences, Tawhid, Fiqh and ushul Fiqh, Ahlak Tasawuf, dates, Arabic, Nahwu Shorof, Balaghoh, and Kalam Science. Tahsinut Tilawah by practicing reading al-Qur'an bi nadhor $30 \mathrm{Juz}$ by explaining and applying the recitation knowledge. Tahsinut Tilawah includes; Tahfizhul Koran do to form of memorizing Koran juz 30 from surah an-Naba' to surah an-Nas, as well as several selected surahs which involve surah as-Sajadah, Yasin, ad-Dhukhan, Al-Mulk, al-Waqiah, and al-Kahf.

The Interpretation subjects EDF Ulya level consist of two materials, namely Tafsir Interpretation and tafsir science. Tafsir is the product understanding of the commentators to the Holy Koran while the Tafsir science is the knowledge that becomes a tool for a commentator to be able to interpret the Koran correctly. So that a commentator does not arbitrarily interpret the Koran in his mind. Tafsir-Tafsir subject in EDF Ulya has 3 goals namely; santri are able to read and understand interpretations of the Koran properly and correctly based on authoritative commentaries on boarding schools. Student (santri) are able to understand theories and rules depth based on trust (mu'tamad) interpretation (ulumul Qur'an) in and santri books expected to practice contents of the Koran in everyday life. The scope of Tafsir-Tafsir science in EDF at Ulya level includes: The Koran Interpretation from surah Al-Fatihah to surah An-Nas based on interpretive books that are mu'tamad among pesantren, especially Tafsir al- Jalalayn by Jalaludin al-Mahalli and Jalaludin as-Suyuthi and Al Itqon Mabahis Ulum al Quran.

Hadith and the Hadith Sciences in EDF at Ulya Level is an improvement from the Hadith that have been studied by students at Ulya level. The improvement was carried out by studying, deepening and enriching study of the Hadith, especially regarding scientific basis in preparation for continuing to higher education, as well as understanding and applying themes about commendable and despicable qualities morals that must be shunned in Hadith perspective as a preparation for social life. Subjects of Hadith-Science Hadith in this EDF has 4 objectives; increase students' love to the hadith, equip students with arguments contained in the hadith as a guide in addressing and dealing with life, increase understanding and experience in terms hadith both scientific content and equip skills to trace hadith from original source and assess the quantity and quality. The Hadith book used and taught in EDF Ulya level covering Riyadhus Sholikhin. While Matan Baiquni is the book of hadith which is taught in EDF at Ulya level.

Tauhid subjects in EDF Ulya level function as a deepening and habituation of Islamic faith values that have been learned by students in the education unit. Monotheistic (Tauhid) learning emphasizes ability to understand the principles of Islamic creed as true beliefs and maintain them, as well as live up to and practice the exemplary values that emanate from the nature of God in al-asma 'al-husna. Tawheed taught on EDF Ulya aims to; strengthening faith through giving nourish and developing knowledge, comprehension, practice, habituation and experience of students about Islamic creed so that they become Muslim 
people who continue to develop their faith and piety to Allah SWT. Motivating students to learn and practice teachings of Islamic creeds that are inclusive behavior in daily life form habituation. Prepare students to be able to read texts on Arabic monotheism material (islamic classical manuscript) at upper secondary level, so that they are ready to continue to higher education. The monotheism book taught is Khosyiyah fil i'tiqod book.

The Fiqh and Ushul Fiqh at Ulya EDF are a subject that studies how to worship, especially concerning comprehension and understanding Islamic law (syariah) and rules through proving the law method of Ushul Fiqh. Fiqh and Ushul Fiqh books taught in Ulya EDF are Fatkhul Mu'in, and Lathoiful Isyaroh. The Fiqh-Usul Fiqh subject in EDF aims to equip students involeve students to know and understand the principles, rules and procedures for law implementation both concerning worship aspects and muamalah. Secondly, students can implement and practice provisions properly and well Islamic law. Thirdly, students can recognize, understand and appreciate source Islamic law by utilizing proposal rules fiqh and fiqh as a method of showing and developing Islamic law from its source. Fourth, applying principles arguments syaria discussion 'in the context Islamic law giving birth to taken from its arguments to be practiced in everyday life.

Akhlaq-tasawuf in Education Diniyah Formal at Ulya level EDF is a subject to improve morals and spirituality that have been studied by students at Education Diniyah Formal at Ulya level. Substantially subject of morality-tasawuf has a contribution at motivation students for learn and practice morality-Sufism in forming habituation in perform commendable morals and avoid ignoble morals in everyday life. The objectives Akhlaq-Tasawuf lesson in EDF Ulya are; to realize Indonesian people who have noble character and avoid ignoble morals in everyday life. Another goal is to realize Indonesian people who have clean hearts and can draw closer to Allah in spirituality, as teachings and values implementation of Sufism in daily life. The Ahlak tasawuf book taught in this Ulya EDF is the Kifayatul Atqiya Book.

The subject Historical in EDF, in general is to examine the origin, development, and Islamic culture role civilization in the past from the missionary endeavor development period Islam by the Prophet Muhammad, both in Indonesia and in the world. Historical learning taught in EDF is the Ash Shiroh An Nabawiyah Book.

The purpose thought historical study in EDF is to build students 'awareness about the importance teachings and learning norms values foundations that have been built by the Prophet Muhammad in order to develop Islamic culture and civilization. Beside to build students' awareness about the importance of time and place which is the past, present, and future process. The other purpose is for train critically students to correctly understand historical facts based on a scientific approach.

The Arabic subjects in EDF Ulya are directed to encourage, guide, develop and foster abilities and foster positive attitudes towards Arabic both receptive and productive. The book taught in Arabic subjects in EDF Ulya is Al 'Arrobiyyah Baina Yadaik. Arabic learning aim is to equip students with the ability to master language components related morphology, (contextual mufrodat and like ishtilahiyyah) practical and functional structure. The second goal is to equip students with four Arabic language skills, especially speaking and writing skills, which can be actively applied in carrying out communication in Arabic at pesantren. Third, developing oral and written communication skills with native Arabic speakers acceptable in daily life context.

Nahwu-Sharf subjects are generally taught to santri so that santri (student) can demonstrate the Alfiyah Ibn Aqil's nazham memorization fluently. Santri can understand and explain the structure and sentences of words contained in Arabic texts. Nahwu-Sharf 
subjects have three goals. Students can understand the word forms analysis and relationships patterns between words in Arabic sentences to explain grammatical speech meaning, students can understand and produce Islamic texts in Arabic, both oral and written, students are able to realize importance of nahwu and sharf as subjects that have a role as instrumental sciences in exploring the Islamic religious sciences.

Balaghah subjects in EDF Ulya are very closely related to Arabic and Nahwu-Sharf subjects. Balaghah discusses how use skills and language elements, including structure Nahwu-Sharf, in oral and written communication, including in communicating God and His creatures, especially humans, in al-Qur'an is al-Karim. The book taught in this Ulya EDF is Al Jauharul maknun. Teaching purpose this book is for students to be able to read and understand Arabic Kalam texts both poetry (syi'ir) and prose (natsar) especially the Koran verses, properly and correctly, students are able to mention and explain words meaning or expressions that contain balaghah aspects in a text. Students can develop the interrelations understanding between language and culture, as well as broadening cultural horizons, including Islamic Arabic culture. The book taught on this EDF is A1 Iqtishod Fil Iqtiqod.

The subject Kalam Science in Formal Diniyah Education Ulya level aims to make students have ability to understand and distinguish factually and conceptually kalam thoughts right and wrong (misguided), have an attitude diversity or faith that who hold fast Ahl al-Sunnah wa al-Jama'ah moderate and loving (rahmah). The goal developed by Ulya EDF on the subject Kalam Science is to develop the creed of Ahl al-Sunnah wa al-Jama'ah as a moderate and grace creed, students are able to cultivate themselves as Indonesian Muslims who believe and fear Allah SWT with a humble attitude, so they do not have selfclaim attitude to be a true Muslim and other Muslims are wrong (inner) and have opportunity to continue education at a higher level. Another goal is for students to manifest themselves as Indonesian Muslims who adhere to Ahl al-Sunnah wa al-Jama'ah and have a noble character with a great love for the country and the United State of the Republic of Indonesia.

\subsection{Hidden curriculum}

The hidden curriculum is an undocumented curriculum in education process on Islamic boarding schools in general and EDF specifically. However, hidden curriculum is existence according to the researchers, has a big influence on formation of students' character. This is because all activities carried out by controlled students begin to wake up to sleep again in Islamic boarding school. This hidden curriculum here is in habituation form of students during their education at Islamic boarding schools. This habituation is expected to take root in the students personality when students graduate truly become mutafaqqih fiddin Ulama who have a sincerity spirit, simplicity, independence, brotherhood among Muslims, humble, tawadlu, tolerant (tasamuh), equality (tawazun), moderate (tawasuthuh), the exemplary /be role model (uswah), healthy lifestyle, and love of the motherland in accordance with the purpose as stated in Minister of Religion regulation No. 13 Year 2014.

\section{The output of Santri Mutafaqqih fiddin and has tolerant values and nationalism}

From entire learning process in EDF on Walindo, APIK, al Mahrusyiyyah, Cokrokertopati and EDF AL Mubaarok research subjects, it was obtained that the formation of santri mutafaqqih fiddin, moderate and animating the values of sincerity, simplicity, 
independence, brotherhood among Muslims, humility, humility tawadlu, tolerant (tasamuh), equality (tawazun), moderate (tawasuth), exemplary (uswah), healthy lifestyle, and patriotism are strongly influenced by hidden curriculum of pesantren culture as a part of of EDF. In the theory material about mutafaqqih fiddin and tolerant values is in factual curriculum, but alone not enough without the reinforcement carried out in practice of daily life in pesantren. The hidden curriculum has been entrenched to student's daily lives both in general and EDF.

A sincere life culture has been instilled since santri set foot in the pesantren and EDF. Since officially becoming a boarding school santri and EDF students must be sincere and obedient to follow the pesantren rules such as meeting with the opposite sex (dating) not wearing jeans, not having a mobile phone, not being able to see television and radio, and so forth. Ikhlas shared when bringing presents brought by studentss parents. The students are accustomed cleaning worldly things from develop character arrogant or charity must due to Allah.

Since the first day, all students were "impoverished" by EDF and boarding schools. The students from among wealthy parents (even wealthy) even great Kiai's son at the other Islamic boarding school is treated the same as other students who are not from the wealthy parents or the line scholars religious. Impoverishment purpose regulations do not allow students to keep money privately and must be entrusted to the boarding school administrators, not to wear branded clothes. Every day wearing gloves, clothes, and white cap for male students, while for female students should not wear powder, jewelry and so forth.

Simplicity is intentionally cultivated in the santri spirit to instill strength, fortitude in face of all difficulties, and to share the others suffering in the future. More than that simplicity can also cause a solidarity sense, feel togetherness beauty among students themselves. Simplicity does not mean that life is poor or destitute, not that it is, but simple is a person not arrogant, and feel noble. Santri can live rich or even rich. But the wealth is for the benefit and the people welfare.

The independence culture is also always instilled by EDF through daily life in pesantren. After first embed a sincere charity and simplicity spirit, students must learn more independently to take care of themselves without depending on others. Independence training is the key for santri in particular and pesantren in general to take care of their interests. Islamic boarding school strives to never lean their lives towards help and mercy of others. From the first day all students were trained to be independent, wash their clothes, iron their clothes and so on. However, in terms of breakfast and evening meals are still provided by the cottage in the form of "mayoran" which is one tray for 4-6 people.

The brotherood culture muslims fellow generally implanted in boarding schools and specifically through EDF Ulya both within the boarding school environment and outside the boarding school. Within the pesantren environment as well as EDF brotherood muslims culture fellow can take the form of cooperation (namely ro'an) and Santri League. The brotherhood muslim culture embed aims to foster an atmosphere and brotherhood sense that is thick, close, unpretentious, unity, cooperation both in EDF, in boarding schools and even brought up to the cottage. By embed the brotherhood Muslims culture it is expected that a sense of pleasure will grow alongside other muslim community regardless status, class, and every muslim. Organization. It is expected that after graduating from these boarding school students as Ulama cadres can embrace Muslim people so that they break in pieces.

Humility and humble (tawadhu) cultivation sowing pesantren to santi EDF by implementing a simple life. Kyai and asatidz treat the students without favoritism. All EDF 
students are treated the same in their social regardless, economic or hereditary status. Asatidz and Kyai rarely give excessive praise to their students. Cultivativing a sense santri's modest and humble in EDF Ulya was also given direction and guidance by mudabbir pondok (santri supervisor), so that they do not boast of their rich. The humility and humble cultivation aim to make students after graduation become cadres of Ulama who are always humble, and always live modestly.

Tolerant culture developing through education both in EDF in boarding school environment. The material for tolerance is integrated through citizenship education both with the government curriculum and curriculum Islamic boarding school in Classical Islamic Manuscript form lessons. In EDF curriculum ulya, civic education material uses the materials in student worksheet (LKS). Whereas the Classical Islamic Manuscript EDF uses the book Ibn Khaldun and al ahkam sulthoniyah preamble. However, for Muqodimmah Ibn Khaldun and ahkam sulthoniyah has not been 100 percent given to EDF students, because obtaining the difficulty in this book.

If a student has a tolerant spirit, he will have a moderate character attitude towards the reality in his environment. Thus, when santri already have moderate character attitude. It also grows equality (tawazun) within the santri in daily behavior be able to deal with resolve existing problems more clearly in equal. In develop character attitude of this tolerant and tawasuth in particular relationship between minna (in one religious) and minhum (interreligious) EDF in general pesantren specifically follows national figures or scholars, such as Habib Lutfi bin Yahya and KH. Abdurrahman Wahid. These figures are known synonymous with tolerance teachings.

Tolerance, moderate and equality is one thing that cannot be separated. Tolerance is the concept, there must be something different between one another in Islamic life in sociable, especially in faith terms, then Muslims must remain opposed to friends, but not interfere with each other. tolerance means respecting differences and respecting people who have life different principles. Developing moderate attitude (tawasuth) is the proceeds grow tolerant value. Instilling value material tolerant and moderate values in EDF will ultimately produce result in form of a balanced attitude in the facing of life.

The method exemplified in daily behavior, for example in the clothes case that are always neat, clean and cover the genitals. Asatidz had given an example how to behave in a fashion with his students. It is not enough, to just be neat but must be clean and cover the genitals. For that, the clothes that are used asatidz here are white or plain clothes so that cleanliness and neatness can be seen asatidz whose expectations are imitated by students.

Healthy lifestyle taught through daily life practice in Islamic boarding schools. Although in Ulya's EDF learning, there is also material about healthy lifestyles. At practice level, pesantren culture teaches a lot about healthy lifestyles. Santri EDF Ulya is taught to maintain a healthy lifestyle by maintaining health and hygiene in the pesantren environment. Kyai's pesantren especially the cleanliness and health section make rules to clean the environment around the pesantren. The program supports cleanliness done by making daily picket schedule both the daily room picket schedule and the boarding school daily picket schedule.

Related to patriotism value, the actualization values nationality is formally carried out by Islamic boarding schools through EDF. Education Diniyah Formal is one of strategies to produce santri as ulamas cadres in protecting the United Republic of Indonesia (NKRI) by counteracting radicalism. The pesantren actualization and expression forms of EDF and students are outlined in the daily life in the pesantren environment. For example, singing the song Indonesia Raya, 17 August, Dari Sabang Sampai Merauke and Yal Lal Wathon, 
Bagimu Negeri, Maju Tak gentar and so forth after the Duha prayer or at around $07.30 \mathrm{o}$ clock. The habituation the national anthem song has been going on for years or since the boarding school was established.

The love of habituation to the motherland is also carried out through symbols in the EDF and the boarding school. The symbols are in the form of flagpoles, pictures of national heroes, especially Kyai Archipelago, pictures of presidents and vice presidents, and also murals on the walls of pesantren.

EDF as an educational institution under the auspices of the salafiyah pesantren affiliated with the Nahdlotul Ulama Organization became frontline in supporting the United State of the Republic of Indonesia. Santri and salafushalih Ulama always search through education in EDF and Islamic boarding schools to form students who are mutafaqqih fiddin (theologians / priests) who love their homeland after leaving the boarding school. Santri and EDF boarding schools must become khoirunass fi anfau linnas (the best of humans is useful for other humans) wherever they are with the knowledge gained from the pesantren.

\section{Conclusions}

Based on the research findings above, this study concludes 2 conclusions as follows.

First, cadres of moderate Ulama who have tolerant values through Diniyah Education Formal are done by processing student input at Islamic boarding school who hold EDF with curriculum and asatidz resources to produce outputs of students as prospective mutafaqqih fiddin scholars (Theologians) and sincere inspirational values simple, tolerant, tawazun, moderate, to be role model, healthy living and loving the motherland.

Secondly, the form of cadre regeneration of moderate and tolerant ulama through EDF at Ulya level is carried out through factual curriculum and hidden curriculum which is a daily culture in EDF. However, among the most instrumental in shaping the character of students who have tolerant values is the implementation of a hidden curriculum as the core of Education Diniyah Formal in Islamic boarding school.

\section{References}

[1] Usman, Sunyoto.Pemuda Ulama, dan Pemilu. Jurnal Ketahanan Nasional. Vol 1 No 1. pp. 6778 (1996). https://doi.org/10.22146/jkn.10838

[2] Husnan, Dinul and Mukhamad Sholihin.Ulama, Islam, dan Gerakan Politik. Fokus Jurnal Kajian

Keislaman dan Kemasyarakatan. Vol 2 No 1 2017. PP. 1-26 (2017). DOI: http://dx.doi.org/10.29240/jf.v2i1

[3] Anwar, Rosehan et all: Ulama Dalam Penyebaran Pendidikan dan Khazanah keagamaan. Jakarta: Research and Development Project and Religious Education Literature, (2003).

[4] Saekan, Mukhamad: Islamic Nation Unfying Nation. QIJIS: Qudus International Journal of Islamic Studies. Vol 5 Agustus 2017. P. 101-116, (2017). http://dx.doi.org/10.21043/qijis.v5i2.2484

[5] Ministery Religious Affair Regulation No 13 tahun 20014 About Islamic Religious Education, (2014).

[6] Dhofier, Zamakhsyari: Tradisi Pesantren, Studi pandangan Hidup Kiai dan Visinya Mengenai Masa Depan Indonesia. Jakarta: LP3 ES 9th edition. Pp. 79-93, (2011). 
[7] Haedari, Ahmad and Elsaha Ihsan: Peningkatan Mutu Terpadu Pesantren dan Madrasah Diniyah. Jakarta:Diva Pustaka. P. 39, (2004).

[8] Zuhri, Saifuddin: Berangkat dari Pesantren. Jakarta: Gunung Agung, (1987).

[9] Muhtarom: Reproduksi Ulama di Era Globalisasi. Yogyakarta: Pustaka Pelajar. P. 12, (2005).

[10] Suprayogo, Imam: Kiai dan Politik, membaca Citra Kiai Malang: UIN Malang Press. Pp. 4-5, (2009).

[11] Hsubky, Badruddin: Dilema Ulama dan Perubahan Zaman. Jakarta: Gema Insan Press. P. 62, (1995).

[12] Windham, Douglas M: Improving the efficiency of educational system, indicators of educational effectiveness and efficiency. Florida: IEES. Pp. i-iii, (1990). 